\title{
PETROGRAPHY AND GENERAL CHEMICAL FEATURES OF POTASSIC MAFIC TO ULTRAMAFIC ALKALINE VOLCANIC ROCKS OF MATA DA CORDA FORMATION, MINAS GERAIS STATE, BRAZIL.
}

\author{
Sgarbi $^{(1)}$, P.B.A. and Valenca ${ }^{(2)}, J . G$.
}

(1) Instituto de Geociências, Universidade Federal de Minas Gerais. Av. Antonio Carlos, 6627 - 31270 Belo Horizonte - MG; (2) Instituto de Geociências, Universidade Federal do Rio de Janeiro. Cidade Universitária - Ilha do Fundāo - CEP 21910. Rio de Janeiro - RJ, Brazil.

\section{INTRODUCTION}

This abstract focuses on relevant petrographic and chemical features of kamafugitic lavas of the Mata da Corda formation. cropping out near the town of Carmo do Paranaiba (western Minas Gerais state). The studied area (approximately, $450 \mathrm{~km}^{2}$ ) constitutes part of the. Cretaceous Sanfranciscan basin.

\section{GEOLOGY}

The rock succession in the Sanfranciscan basin represented by the Areado (hereafter called AR) and Mata da Corda (hereafter called MT) formations, is $500 \mathrm{~m}$ thick and unconformably overlies folded metapelites of the Upper Proterozoic Bambui group. The AR formation (Lower Cretaceous) consists of fluvial polymictic conglomerates (Abaete member), lacustrine shales, sandistones, limestones and marls (Quirico member), and aeolian and fluviodeltalc sandetones (Tres Barrae merber). The MT formation (Upper cretaceous) overlies the latter formation. from which is sepereted by local erosive unconformities. It comprises a 40 to $50 \mathrm{~m}$ thick pile of K-rich mafic to ultramafic alkaline lavas (Fatos facies). volcanic conglomerates and sandstones (Capacete facies) and clayey sandstones with little volcanic contribution (Urucuia facies). The lavas and non-volcanoclastic rocks have a larger spatial

distribution and are volumetrically more significant than the volcanoclastic rocks. The lavas form small exposures (frequently, very weathered) of massive, thin horizontal and subhorizontal. poorly-vesiculated flows (in places, individually, not exceeding $0.5 \mathrm{~m}$ thick). In some outcrops, the extrapolated thickness of a sequence of flowe may reach $10 \mathrm{~m}$.

\section{PETROGRAPHY}

Under the IUGS scheme (Streckeisen, 1980) the MT lavas are ultramafitites, mafitites, leucitites and kalsilitites (hereafter called, respectively ULT, MAF, IEU and KAL). These UIT and MAF have unidentified felsic phase(s) and estimated values (vol. \%) of mafic index from 80 to 70 and 60 to 70 , respectively; whereas the IEU and KAL contain leucite (pseudomorphe) and kalsilite (pseudomorphs and fresh and clear grains), and get their names from that felsic phase present in larger amount. In addition, the lavas are all feldspar-free. with abundant clinopyroxene (mostly. dopside), perowskite and Ti- magnetite, and very fine to mediumgrained porphyritic to seriated textures. An interstitial material is always present and often intensely aitered to zeolites and clay minerals. In some rocks it has been determined as kalsilite based on electron microprobe analysis: but in other rocks this material could not be accurately identified and it has been modaliy considered as an unidentified felsic phase.

The UIT and MAF are porphyritic to seriated rocks. The porphyritic types show phenocrysts (up to 20 vol.\%, and 0.2 to 2.0 $\mathrm{mm}$ in size) of olivine (FOg1-85), clinopyroxene (diopside). perowskite, Ti-magnetite, melilite (euhedral arid subhedral pseudomorphs), apatite and phlogopite (rarely, as 3 . 0 mra large plates). The very fine to fine-grained groundmass has clinopyroxene (diopside, up to $50 \%$ ). Ti-magnetite, perawsite unidentified interetitial material, and may also contain minor amounts of phlogopite and apatite. The seriated types have coarser grains but are modally and mireralogically akin to the rrevious types. 
The LEU and KAI are very similar fine to medium-grained rocks, very frequertly. with a typical seriated texture. Some of them. however may develop textures which resemble those of the UIT and MAF Mineralogically. The LEU and KAI are similar to the latter groups of rock. with the exception that they contain leucite (subhedral pseudomorphs) and kalsilite (euhedral pseudomorphs and/or anhedral fresh grains). Both feldspathoids occur as essential phases in the seriated LEU and KAI or in the very finegrained intergranular groundmass of the porphyritic LEU. In these porphyritic rocks, the feldspathoids, in spite of being found in the groundmass, are absent from the phenocrysts and microphenocrysts. which consist of clinopyroxene (diopside to salitel. Ti-magnetite, apatite and perowskite.

The above mentioned rocks (usually, the fine-grained types) may contain scarce and small (mostly, \& 20 mo across) cograte inclusions of fine to medium-grained cumulate rocks, consisting of diopside, perowskite. Ti-magnetite, phlogopite and kalsilite. Most commonly, the inclusions are of kalsilite pyroxenites, but more rarely, perowskite modally dominates and they become halsilite "perciskitites". In both cases, kalsilite is an interstitial phase.

\section{CHEMISTRY}

Twenty-three samples of the MT lavas have been chemically analised (results not fully given). These data indlcate that: the lavas are ail ultrabasic and the majority falls into two distinct groups (GI and GII), according to the $\mathrm{K}_{2} \mathrm{O} / \mathrm{Na}_{2} \mathrm{O}$ and $\mathrm{K} \mathrm{O}_{2}$ values. GI $1 \mathrm{~s}$ potassic and has (WT\%) $\mathrm{SiO}_{2}=38-42$, $\mathrm{TiO}=5-7$. $\mathrm{Al}_{2} \mathrm{O}_{3}=5-8, \quad \mathrm{~F}_{2} \mathrm{O}_{3}>4<5, \mathrm{~F} \in \mathrm{O}=8-9, \mathrm{MgO}=8-14, \mathrm{CaO}=11-17, \mathrm{~K}_{2} \mathrm{O}=1-3$, and $\mathrm{Na}_{2} \mathrm{O}>0-2$ : whereas GII is ultrapotassic, with (WT\%) $\mathrm{S}_{10}=43-45$. $\mathrm{TiO}_{2}=5-6, \mathrm{Al}_{2} \mathrm{O}_{3}=7-9, \mathrm{Fe}_{2} \mathrm{O}_{3}>3<4, \mathrm{FeO}=7-9, \mathrm{MgO}=6-9, \mathrm{CaO}=8-12, \mathrm{~K} 2 \mathrm{O}=$ 4-7 and $\mathrm{Na}_{2} \mathrm{O}>\mathrm{O}-2$. (2) In the $\mathrm{Na}_{2} \mathrm{O}+\mathrm{K}_{2} \mathrm{O}$. versus $\mathrm{SiO}_{2}$ plot, the compositions delineate a broad trend from moderately (GI) to strongly (GII) alkaline. (3) The compositional spectrum of the lavas shows mainly non-iinear variation trends of increasing $S_{i}$ $\mathrm{Al}_{2} \mathrm{O}_{3}, \mathrm{~K}_{2} \mathrm{O}$. Na $\mathrm{Na}_{2} \mathrm{O} \mathrm{Nb}$, Ir and $\mathrm{Y}$, and decreasing FeO, CaO, Cr and Co, with decreasing Mgo. (4) Discrimination diagrams using $\Xi_{2} \mathrm{O}_{2}$. CaO. Mgo, and Feo (total tron) exhibit most lava compositions in fields of kamafugitic affinity.

\section{SUMMARY AND CONCLUSIONS}

The evidence on the Mata da Corda (MT) lavas in this work suggests that: (1) Because of the uncertainties in the mineralogy and modal analysis it is dificult to $9 s t a b l i s h$ a clear correspondance between petrographic and chemical (potassic and ultrapotassic) groups for these lavas. (2) The observed chemical compositional variations of the lavas are consistent with an evolutionary general trend from potassic. Mg-richer and moderately alkaline to ultrapotassic. Mg-poorer and strongly alkaline members. Low-pressure arystal fractionation of cilnopyroxene. olivine, perowskite and magnetite, probably controlied this trend. (3) Cretaceous "lamproites" (Leonardos et $s 1$. 1990) and kimberlites and lamprophyres (Svisero et ai. ig79) have been reported in the general region, but the available petrography. mineralogy and chemistry of the Cretaceous K-rich MT lavas, in the area, are more compatible with a kamafugitic afinity.

\section{REFERENCES}

Leonardos, O.H. Ulbrich, M. E Gierth. E. (1990). "Lamproitos": uma fonte alternativa para os diamantes do Alto Paranaiba. xxxis Congresso Erasileiro de Geologí. Bol. de Resumos. 120.

Streckeisen, A. (1980). Classification and romenclature of volcanic rocks, carbonatites and melilitic rocks. IUGS subcomission on the systematics of igneous rocks. Geologische Rundschau 69, 194-207.

Svisero, D.P. Hasui, Y. E Drumond, D. (1979). Goologia de Kimberlitos do Alto paranaiba. Minas Gerais (Geology of kimberlites of the Upper Paranaiba. Minas Gerais). Min. Metall. $42 \quad 34-38$ 